\title{
Assessing social and spiritual needs of hospice patients A feasibility study
}

\section{E. de Graaf, A.H.M. Lormans, M. de Leeuw, F.H. van der Baan, S.C.C.M. Teunissen}

\section{Background}

Hospice care aims to optimize the quality of life by diminishing suffering in the physical, psychological, social and spiritual dimension. The four dimensional Utrecht Symptom Diary (USD4D) is developed based on the Ars Moriendi model to monitor problems in the social and spiritual dimension and support scial and spiritual care.

Aim

To gain insight into the feasibility of the USD4D as a basis for social and spiritual care for hospice patients.

\begin{tabular}{|c|c|}
\hline $\begin{array}{l}\text { Method } \\
\text { A feasibility study with } \\
\text { performed in } 2017 .\end{array}$ & a explanatory mixed method design was \\
\hline Population & \\
\hline Phase 1A \& 1B & $\begin{array}{l}\text { Patients who died 2016, } \\
\text { at least one USD4D, admitted } 2 \text { wks }-3 \text { months }\end{array}$ \\
\hline Phase 2 & Multidisciplinary teams \\
\hline Outcomes & \\
\hline $\begin{array}{l}\text { Demand, practicality ar } \\
\text { Data collection }\end{array}$ & nd acceptibility \\
\hline $\begin{array}{l}\text { Data collection } \\
\text { Phase 1A Quantitative }\end{array}$ & \\
\hline $\begin{array}{l}\text { Phase 1A Quantitative } \\
\text { Phase 1B Quantitative }\end{array}$ & USD4D database \\
\hline $\begin{array}{l}\text { Phase 1B Quantitative } \\
\text { Phase? Oualitative }\end{array}$ & 30 records ( 10 hospices) \\
\hline Analysis & rocusgroup interviews \\
\hline Phase 1 Quantitative & Descriptive statistics \\
\hline Phase 2 Qualitative & Thematic analysis \\
\hline
\end{tabular}

\section{UMC Utrecht}
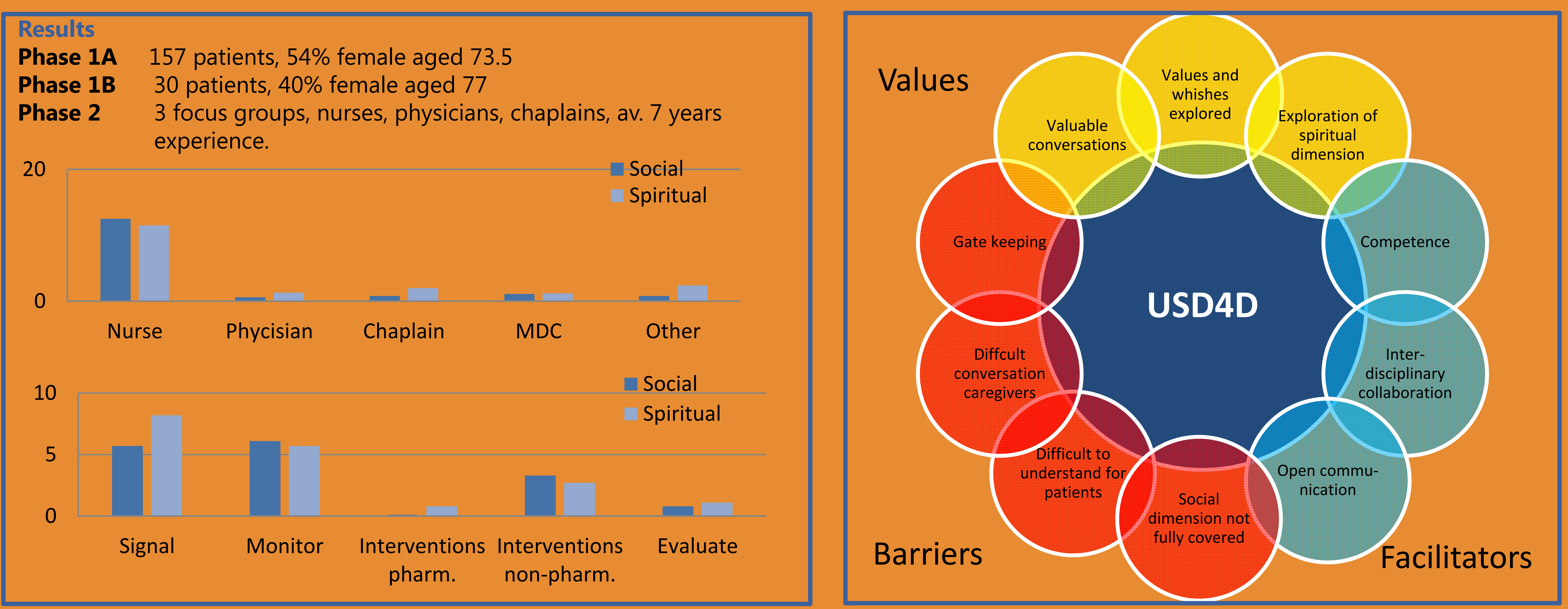

\section{Conclusion}

Hospice patients were able to use the USD4D in daily hospice care. Nurses are predominantly responsible for the documentation of social and spiritual needs of patients. The USD4D supported social and spiritual care and provided words in patiënt communication and interdisciplinary consultation.
Gatekeeping by caregivers is the main reason for missing measurements. Reasons mentioned were: too difficult to understand, too emotional for patients. However, this was not discussed with patients. Integration of the USD4D in daily practice requires intedisciplinary collaboration, open communication and competences of all members of the multidisciplinary team.
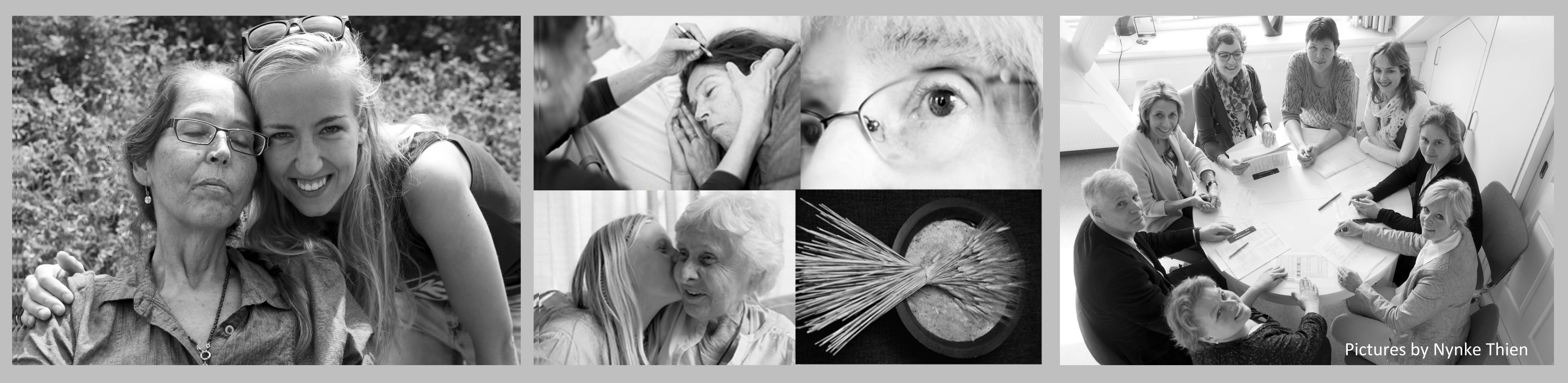